\title{
Craspedacusta cf. sowerbii Lankester, 1880 (Cnidaria: Hydrozoa: Limnomedusae): New record for the middle plateau region of the state of Rio Grande do Sul, Brazil
}

\author{
Marcoandre Savaris ${ }^{*}$, Silvana Lampert and Maria Angélica Haddad \\ Universidade Federal do Paraná, Departamento de Zoologia, Centro Politécnico, Jardim das Américas. Caixa Postal 19020. CEP 81531-980, \\ Curitiba, PR, Brazil. \\ * Corresponding author. E-mail: masavaris@yahoo.com.br
}

\begin{abstract}
This study reports a new record of Craspedacusta cf. sowerbii for the Municipality of Passo Fundo, located in the central plateau region of the State of Rio Grande do Sul. The C. cf. sowerbii specimens were collected in May 2010 in an artificial lake formed by the flooding of a former basaltic quarry. The lake is $665 \mathrm{~m}$ above sea level and its surface area measures around $25.000 \mathrm{~m}^{2}$. Its crystalline water is linked by the Miranda creek to the Passo Fundo River, part of the Uruguay River basin.
\end{abstract}

Craspedacusta sowerbii is a freshwater hydrozoan species commonly observed in the medusa stage. The species bloom sazonally in lakes, rivers, reservoirs and in natural and artificial ponds, having mainly a subtropical to temperate distribution (Acker and Muscat 1976; Jankowski 2001; Jankowski et al. 2008; Jakovčev-Todorović et al. 2010; Schwarzbold et al. 2010; Gasith et al. 2011). A small polyp present in its life cycle can remain undetectable for years before a medusa "bloom". Regarding dispersion, it is less likely the short-lived medusa stage but the minute polyp carried on aquatic plants, or any of the asexual reproductive phases such as frustules that play the role as a dispersive stage (Dejdar 1934; Reisinger 1957).

The genus Craspedacusta (Olindiidae) was erected by Lankester (1880) for C. sowerbii discovered in a artificial lake at the Kew Gardens in London (Zhang et al. 2009) Although some controversy does exist, the origin of the species has been since then attributed to the Yangtze River basin in China, from where numerous species and subspecies of Craspedacusta have been described. After its description, the presence of $C$. sowerbii has been registered in all continents, except Antarctica (Silva and Roche 2007; Jankowski et al. 2008). However, Zhang et al. (2009) found three valid species for China after phylogenetic analysis based on DNA technology (C. sowerbii, $C$. sinensis and $C$. kiatingi), but the authors considered the morphological characters of these species inconsistent with their results. On the other hand, Fritz et al. (2009) found the German populations of Craspedacusta spp. more related genetically to $C$. kiatingi than to $C$. sowerbii. So, in order to avoid misidentifications on the species, we named the species found in Rio Grande do Sul as $C$. cf. sowerbii.

In South America, the species has been reported in Argentina, Chile, Venezuela and Brazil (Schlenz 1981). In the later, information about eight preterit occurrences in the states of Goiás, Tocantins, Mato Grosso do Sul, São Paulo, Rio de Janeiro, Minas Gerais, Paraná and Rio Grande do Sul are summarized in Silva and Roche (2007). Recently, Schwarzbold et al. (2010) published the second occurrence for the State of Rio Grande do Sul and, Souza and Ladeira (2011) for the State of Minas Gerais.

Gliesh (1930) recorded the presence of polyps and medusae of $C$. cf. sowerbii, (cited as Microhydra spec.) in an aquarium at the Universidade Federal do Rio Grande do Sul. Schwarzbold et al. (2010) recorded a C. cf. sowerbii "bloom" for Rio Grande do Sul, in the reservoir of the Quatorze de Julho Hydroelectric Power Plant, in das Antas River, municipality of Cotiporã, between May and July 2009.

Craspedacusta cf. sowerbii is considered an exotic species in Brazil and its presence in the country is poorly documented. Ecological data are still scarce (Silva and Roche 2007; Schwarzbold et al. 2010). Thus, this report of a new record of the species in southern Brazil is important in order to establish geographical distribution, dispersion capacity and introduction records more accurate.

The specimens of $C$. cf. sowerbii (Figure 1) were collected by two of the authors (MS and SL) in May 29 2010 , in an artificial lake formed by the flooding of a former basaltic quarry (28 $8^{\circ} 13^{\prime} 43^{\prime \prime} \mathrm{S}, 52^{\circ} 21^{\prime} 40^{\prime \prime} \mathrm{W}$; Figure 2), in the municipality of Passo Fundo, State of Rio Grande do Sul. The lake is $665 \mathrm{~m}$ above sea level and its surface area measures around $25.000 \mathrm{~m}^{2}$. Its crystalline waters are linked by the Miranda creek to the Passo Fundo River, which, in its turn, is part of the Uruguay River basin.

The medusae were collected with a cup from the water surface by the shore, and were preserved in $4 \%$ formaldehyde solution. Five specimens were deposited in the Cnidaria collection of the Museu de Zoologia da Universidade de São Paulo (MZUSP, number 001763), and other five, in the Cnidaria collection of the Departamento de Zoologia da Universidade Federal do Paraná (DZoo-CN, number 000234).

According to Bouillon et al. (2006), the species' classification is:

Phylum Cnidaria

Superclass Hydrozoa

Class Hydroidomedusa 
Subclass Limnomedusae

Family Olindiidae

Craspedacusta cf. sowerbii Lankester, 1880

The morphology of the specimens agrees with the diagnosis of Jankowski (2001) and Bouillon et al. (2006), which is resumed as follow: statocysts produced into a long centripetal canal, passing through the thickness of the velum and ending blindly near its margin (this character is diagnostic for the genus Craspedacusta); evenly distributed marginal tentacles, all of one kind; tentacle base usually with a parenchymatic endodermal core embedded in umbrellar mesoglea and with nematocysts in groups on papillae; well-developed marginal cnidocyst ring; four simple radial canals, no centripetal canals; hanging, pouchlike "gonads" only on radial canals; no gastric peduncle; no adhesive organs.

The prominent size of the four perradial tentacles is a constant feature in $C$. cf. sowerbii from all parts of the world (Kramp 1950). The marginal tentacles seem all of one kind, but in our formalin preserved specimens they are not of the same size (Figure 1). The size of the medusae varied from 8.1 to $11.5 \mathrm{~mm}$.

Craspedacusta cf. sowerbii shows a worldwide distribution, probably due to its several forms of vegetative
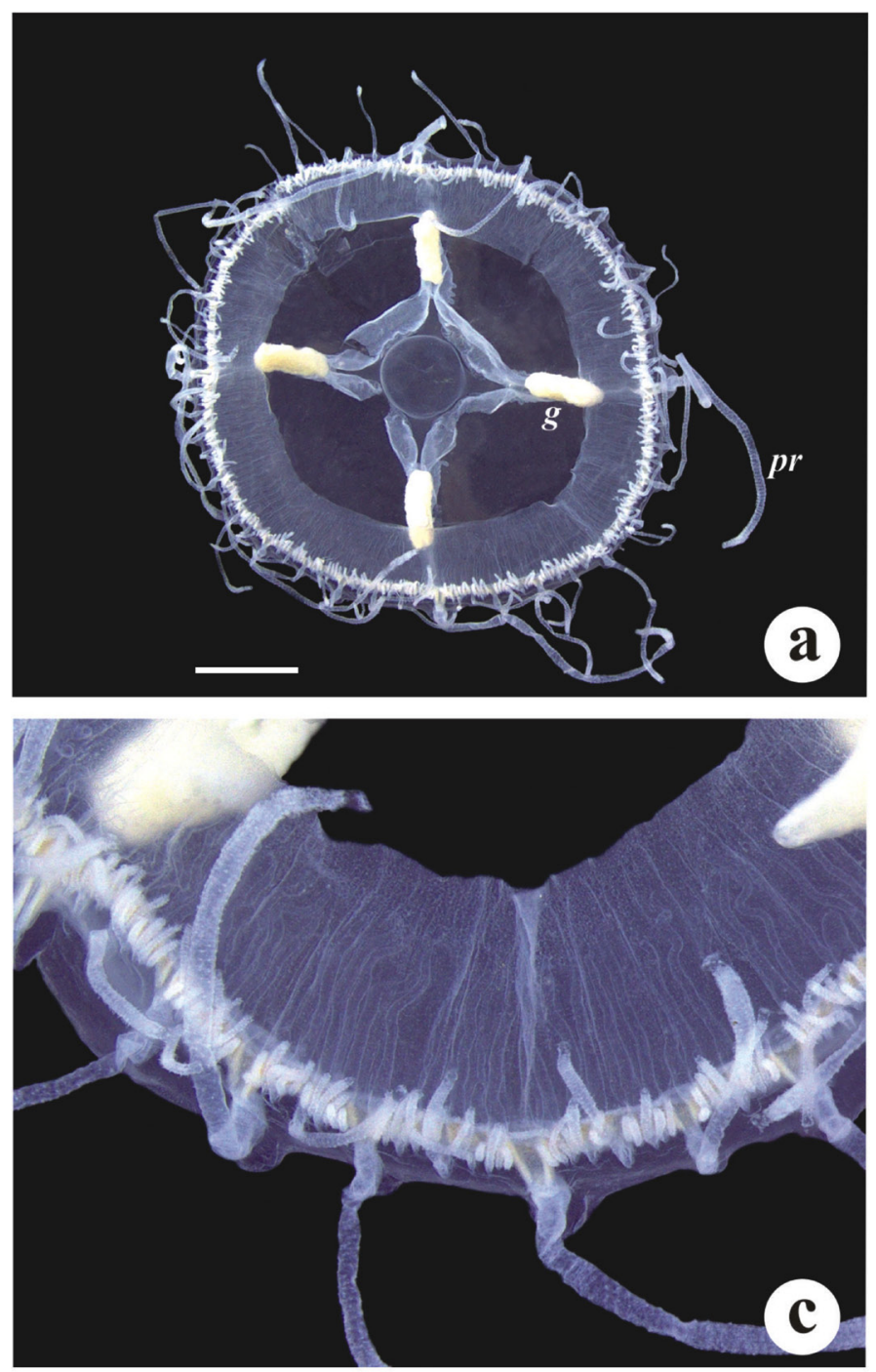

Figure 1. Medusae of Craspedacusta cf. sowerbii from a former basaltic quarry flooded (municipality of Passo Fundo, State of Rio Grande do Sul). (a) medusa in aboral view, Scale: $2 \mathrm{~mm}$; (b) medusa in oral view; (c) detail of medusa margin; (d) margin and velum detail. $p r=$ perradial tentacle; $s c=$ statocysts centripetal canals in the velum; $t c=$ endodermal core of tentacle base; $c r=$ cnidocyst ring; $\mathrm{g}=$ gonad on radial canal.
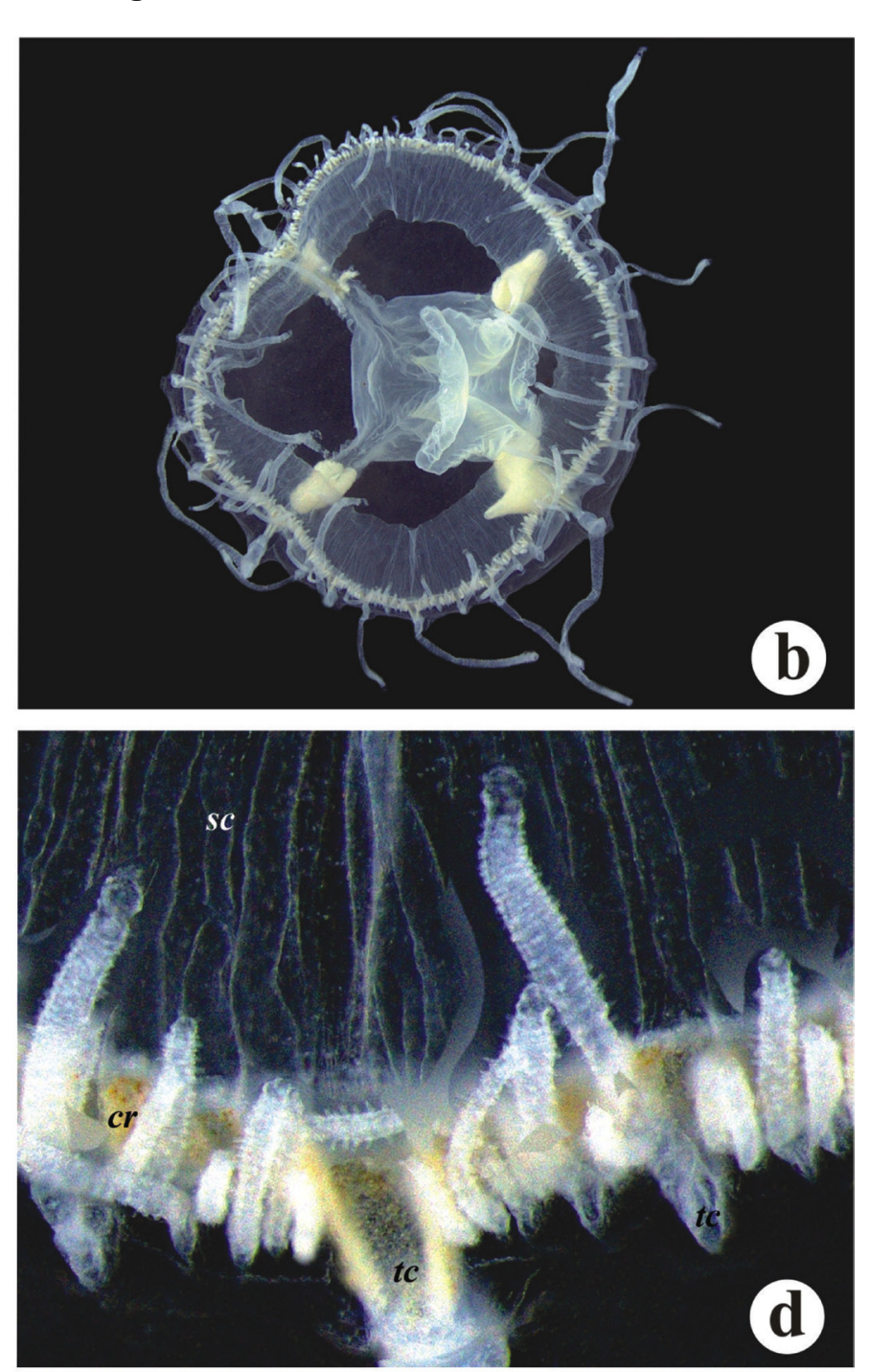

reproduction and ability to survive in adverse conditions (Acker and Muscat 1976; Bouillon and Boero 2000; Fritz et al. 2007).

During the sample procedure, there was a large amount of medusae swimming near the water surface of the artificial pond. The water was transparent, with a temperature of $22^{\circ} \mathrm{C}$. The same swimming behavior near the surface has been observed by Schwarzbold et al.(2010), by Silva and Roche (2007) in a natural calcareous lagoon in Mato Grosso do Sul, and by Souza and Ladeira (2011) in an artificial calcareous pond in Minas Gerais. Schwarzbold et al. (2010) also found $C$. cf. sowerbii medusae in crystalline waters but, in contrast, Silva and Roche (2007) reported that their collection date (April 2006) was at the end of the rainy season, so the water was turbid due to elevated levels of suspended material carried from the surrounding area.

The occurrence of $C$. cf. sowerbii medusae in the central plateau region of Rio Grande do Sul, in addition to that of Schwarzbold et al. (2010) in relatively close period and location (Figure 3), constitute an unprecedented data of the species in Brazil. Two occurrences have also been recorded in Belo Horizonte, State of Minas Gerais, but separated by 60 years (Martins 1941; Souza and Ladeira 2011). Although these two records to the State of Rio Grande do Sul 
come from the same geographic region, the ponds where the medusae appeared belong to distinct hydrographic basins. The artificial lake referred in this study is linked to the Uruguay River basin, at the Northwest side of the plateau, while the Quatorze de Julho Reservoir, where the specimens mentioned by Schwarzbold et al. (2010) were found, is linked to the Jacuí River basin, part of the eastern Lagoa dos Patos hydrographic system. This geographic separation may be a relevant data to future studies on the history of $C$. cf. sowerbii distribution, dispersion and introduction in the state or in the area encompassed by the basins, like that of Fritz et al. $(2007 ; 2009)$, where they detailed the population dynamics of the species within its distributional area in Germany. We also hope that this registration may contribute to future analysis of taxonomy and distribution of the Craspedacusta species complex in continental water of the Brazilian territory.

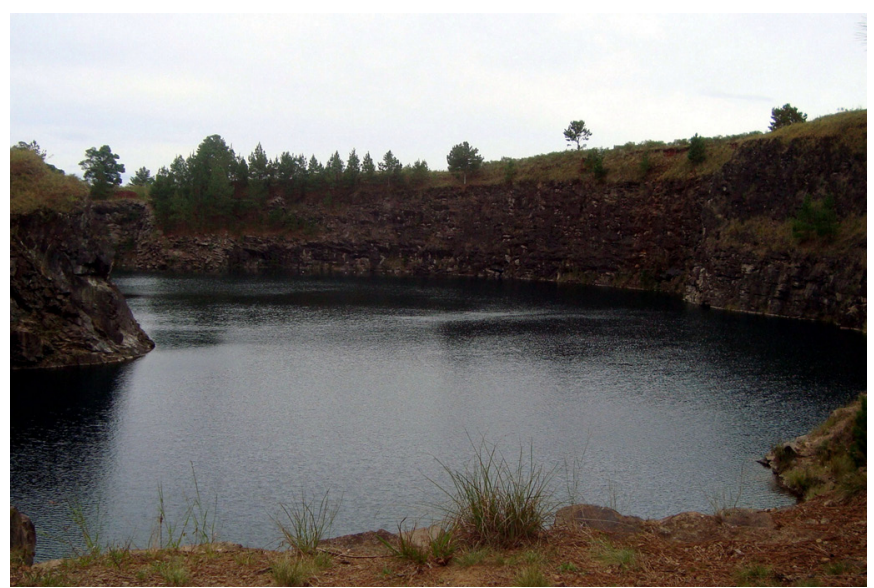

FIGURE 2. Partial view of the lake where Craspedacusta cf. sowerbii were found in the municipality of Passo Fundo, State of Rio Grande do Sul, Brazil.

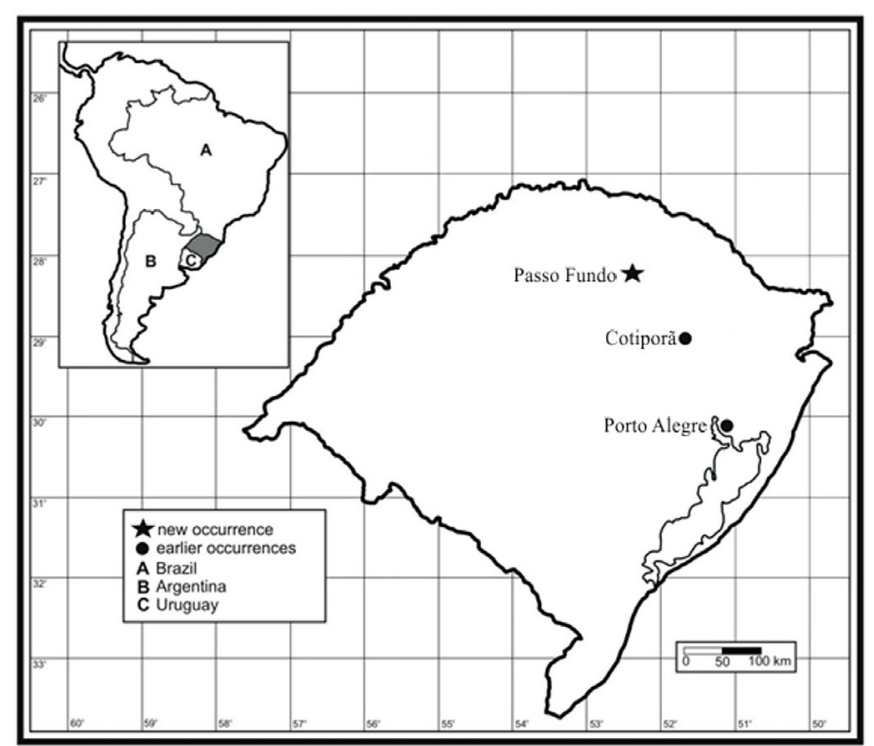

FIGURE 3. Map showing the occurrences of Craspedacusta cf. sowerbii in the State of Rio Grande do Sul.
ACKNowledgments: We thank Dr. Paulo Roberto Valle da Silva Pereira (Embrapa Trigo, Passo Fundo, Rio Grande do Sul) for the map.

\section{Literature Cited}

Acker, T.S. and A.M. Muscat. 1976. Ecology of Craspedacusta sowerbii Lankester, a freshwater hydrozoan. American Midland Naturalist 95 : 323-336.

Bouillon, J. and F. Boero. 2000. The hydrozoa: a new classification in the light of old knowledge. Thalassia Salentina 24: 3-45.

Bouillon, J., C. Gravili, F. Pagès, J.M. Gili and F. Boero. 2006. An introduction to hydrozoa. Memoires du Museum National d'Histoire Naturelle 194: 1-591.

Dejdar, E. 1934. Die Süßwassermeduse Craspedacusta sowerbii Lankester in monographischer Darstellung. Zeitschrift für Morphologie und Ökologie der Tiere, 28: 595-691.

Fritz, G.B., R.O. Schill, M. Pfannkuchen and F. Brümmer. 2007. The freshwater jellyfish Craspedacusta sowerbii Lankester, 1880 (Limnomedusa: Olindiidae) in Germany, with a brief note on its nomenclature. Journal of Limnology 66(1): 54-59.

Fritz, G.B., M. Pfannkuchen, A. Reuner, R.O. Schill and F. Brümmer. 2009. Craspedacusta sowerbii, Lankester 1880: population dispersal analysis using COI and ITS sequences. Journal of Limnology 68(1): 46-52.

Gasith, A., S. Gafny, Y. Hershkovitz, H. Goldsteinand and B.S. Galil. 2011. The invasive freshwater medusa Craspedacusta sowerbii Lankester, 1880 (Hydrozoa: Olindiidae) in Israel. Aquatic Invasions 6(1): 147152.

Gliesch, R. 1930. A medusa de água doce Microhydra spec. Egatea 15: 145-148.

Jakovčev-Todorović, D., V. Đikanović, S. Skorićand P. Cakić. 2010. Freshwater jellyfish Craspedacusta sowerbii Lankester, 1880 (Hydrozoa, Olindiidae) - 50 years' observations in Serbia. Archives of Biological Sciences 62(1): 123-127.

Jankowski, T. 2001. The freshwater medusae of the world a taxonomic and systematic literature study with some remarks on other inland water jellyfish. Hydrobiologia 462: 91-113.

Jankowski, T., A.G. Collins and R. Campbell. 2008. Global diversity of inland water cnidarians. Hydrobiologia 595: 35-40.

Kramp, P.L. 1950. Freshwater medusae in China. Proceedings of the Zoological Society of London 120(1): 165-184.

Lankester, E.R. 1880. On a new jellyfish of the order Trachomedusae, living in fresh water. Nature 22: 147-148.

Martins, A.V. 1941. Sobre a ocorrência da medusa de água doce Craspedacusta sowerbii Lankester, 1880, em Minas Gerais. Revista Brasileira de Biologia 1: 227-230.

Reisinger,E.1957.ZurEntwicklungsgeschichteundEntwicklungsmechanik von Craspedacusta (Hydrozoa, Limnotrachylina). Zeitschrift für Morphologie und Ökologie der Tiere, 45: 656-698.

Schlenz, E. 1981. Coelenterata. In: Hurlbert, S.H., Rodriguez, G. \& Santos, N.D. (eds.) Aquatic Biota of Tropical South America, 2: Anarthropoda. San Diego State University. p. 96-97.

Schwarzbold, A., C. Volkmer-Ribeiro, M.D.C. Vasconcelos, F. Schneckand M. Sponchiado. 2010. Ocorrência de Craspedacusta sowerbii (Hydrozoa: Limnomedusae) (Lankester, 1880) no reservatório da Usina Hidrelétrica 14 de Julho, Rio Grande do Sul, Brasil. Revista Brasileira de Biociências 8(3): 305-307.

Silva, W.M. and K.F. Roche. 2007. Occurrence of the freshwater jellyfish Craspedacusta sowerbii (Lankester, 1880) (Hydrozoa, Limnomedusae) in a calcareous lake in Mato Grosso do Sul, Brazil. Biota Neotropica 7(1): 227-230.

Souza, M.M. and M.K. Ladeira. 2011. Craspedacusta sowerbii Lankester, 1880 (Cnidaria: Hydrozoa: Olindiidae): New record in Minas Gerais state, Brazil. Check List 7(5): 610-611.

Zhang, L.Q., Wang, G.T., Yao, W.J., Li, W.X., and Gao, Q. 2009. Molecular systematics of medusae in the genus Craspedacusta (Cnidaria: Hydrozoa: Limnomedusae) in China with the reference to the identity of species. Journal of Plankton Research 31(5): 563-570.

RECEIVED: September 2012

ACCEPTED: May 2013

Published ONLINE: September 2013

EDITORIAL RESPONSIBILITY: Rodrigo Johnsson 